\title{
MEANING OF PERMANENT LEGAL FORCE ON THE DECISION OF BUSINESS COMPETITION SUPERVISION COMMISSION (KPPU)
}

\author{
Galuh Puspaningrum \\ Doctorate Candidate at Law Faculty, \\ Jember University, \\ Jember, Indonesia \\ galuh.fh@unej.ac.id. \\ Herowati Poesoko \\ Professor of Law Facuty, \\ Jember University, \\ Research fields: Civil Procedure Law and Guarantee Law

\section{Budi Kagramanto} \\ Professor of Law Facuty, \\ Airlangga University, \\ Research fields: Competition Law \\ DOI: 10.31364/SCIRJ/v9.i05.2021.P0521855 \\ http://dx.doi.org/10.31364/SCIRJ/v9.i05.2021.P0521855
}

\begin{abstract}
The decision of the Business Competition Supervisory Commission (KPPU) is the result of the assessment of the Commission Council read out in an open session to the public regarding whether a violation has occurred and the imposition of sanctions or the absence of a violation. The formulation of the KPPU's decision consists of the alleged violation, consideration and assessment of evidence submitted and/or obtained during the trial as well as an analysis of the application of the articles in the Antimonopoly Law which the Reported Party allegedly violated. The KPPU decision is declared to have permanent legal force, if there is no objection from the business actor, and then the KPPU decision must be implemented by the business actor and may be requested for execution at the District Court. Considering the nature and type of KPPU's decisions, when viewed from the types of decisions in civil procedural law, the KPPU's decisions are Condemnatoir decisions, namely decisions that contain punishments and can be implemented. However, the regulations regarding KPPU Decisions that have permanent legal force still do not fulfill the requirements as condemnatoir decisions because KPPU is not a judicial institution and these regulations are still multi-interpretative in nature, namely that legislators do not provide a clear interpretation of the meaning of permanent legal force in KPPU's decisions.
\end{abstract}

Key Words: Meaning, permanent legal force, KPPU's decisions.

\section{Introduction}

The development of case settlement in the economic and business sector in Indonesia has resulted in procedural law and case settlement outside the judiciary. Based on its function, procedural law is used as a legal instrument to maintain material law. The procedural law outside the court is referred to the law of business competition procedure.

Business competition procedure law is a formal law which contains material law. Furthermore, I Made Pasek Diantha in I Made Sarjana ${ }^{1}$ argues that in observing the practice of business competition law enforcement and examining the views of scholars on law enforcement in Indonesia, how important the position of procedural law is, especially the procedural law of

\footnotetext{
1 I Made Pasek Diantha dalam I Made Usaha,(Disertasi:Universitas Airlangga, 2012).h.9

Sarjana, Prinsip Pembuktian dalam Hukum Acara Persaingan
} 
business competition, to not repeat mistakes which have procedural nature. To measure the level of importance of the procedural law, there is a view as follows: "Procedural law is not just any law, but special law which is equivalent to material law because it has a special mission of protecting human rights for the sake of the rule of law."

The application of business competition procedure law is carried out by the Business Competition Supervisory Commission (KPPU) as mandated in Law No. 5 of 1999 concerning the Prohibition of Monopolistic Practices and Unfair Business Competition (hereinafter referred to as Law No.5/1999). The mechanism and procedure for the settlement of business competition cases begins with a preliminary examination and a follow-up examination which ends with the issuance of a decision by the KPPU regarding whether there is a violation of Law No.5/1999 or not.

Taufik Makaro further stated that court decisions that truly create legal certainty and reflect justice, judges as state officials and as representatives of God who carry out the judiciary must really know the actual problem of the case and the legal regulations to be applied, both written legal regulations in laws and unwritten legal regulations. ${ }^{2}$ If the parties involved voluntarily accept the court's decision and do not file an appeal and cassation, the court's decision has permanent legal force.

In regulating the KPPU's decision, Article 46 Paragraph (1) of Law No.5/1999 states that "If there are no objections, the Commission's decision as referred to in Article 43 paragraph (3) has permanent legal force". The purposes and objectives of the Article have not been clearly explained so that they are multi-interpretative, because decisions that have legal force only apply to court decisions, this is of course contrary to the theory and principles of general justice against the meaning of the KPPU's decision in terms of the type and nature of the decision.

Furthermore, L. Budi Kagramanto stated that Law No. 5/1999 in its operational movements still lacks detail in regulating the settlement of cases of violations of the Antimonopoly Law. Law No.5 of 1999 is still unclear in terms of procedural procedures in handling competition cases and the role of the judiciary in handling objections raised by business actors against KPPU's decisions. ${ }^{3}$

Based on the description of thoughts in the background above, it is necessary to conduct an in-depth study and research in order to find the meaning of permanent legal force in the KPPU's decision, because there is a vaguenorm in Article 46 Paragraph (1) of Law No.5/1999, then the formulation of the problem will be discussed in this article is "What is the Meaning of Permanent Legal Force in KPPU's Decision?"

\section{Research Methodology}

The research methodology in this paper uses normative legal research, which is a study conducted by examining and analyzing legal materials and legal issues related to the problems under study. Legal research is carried out to solve problems that arise, while the results to be achieved are in the form of a prescription about what should be done to solve these problems. The approach used in this research is a statute approach, a conceptual approach, a case approach, a comparative approach to law.

The statute approach is to examine all laws and regulations related to the legal issue that is being handled. For the research of practical activities. The Approach to the Law will open opportunities for writer to study the consistency and appropriateness between laws. ${ }^{4}$ The laws in question are Law No.5 of 1999 concerning the Prohibition of Monopolistic Practices and Unfair Business Competition and Perkom No.1 of 2019 concerning Procedures for Handling Cases of Monopolistic Practices and Unfair Business Competition.

A conceptual approach is an approach that departs from the views and doctrines that develop in legal science. By studying the views and doctrines that develop in the science of law, the writer will find ideas that give birth to legal notions, legal

\footnotetext{
2 Taufik Makaro, Pokok-Pokok Hukum Acara Perdata,(Jakarta:Rineka Cipta, 2009),h.124.

3 L. Budi Kagramanto, Larangan Persekongkolan Tender (Perspektif Hukum Persaingan Usaha), (Surabaya:Srikandi, 2008),h.326.

${ }^{4}$ Peter Mahmud Marzuki,Penelitian Hukum,(Jakarta:Prenada Media,2005),h.93

www.scirj.org 
concepts and legal principles that are relevant to the issues at hand. An understanding of these views and doctrines is the basis for the author in building a legal argument in solving the issues at hand. ${ }^{5}$ Thus, the authors use business competition law doctrines.

Case Approach is carried out by examining cases related to the Decision of the Business Competition Supervisory Commission (KPPU), namely Decision on Case Number 27/KPPU-M/2020 concerning Alleged Delay in Notification of Acquisition of Dei Holdings Limited Shares by Travel Circle International (Mauritius) Limited and The Bundeskartellamt verdict on the Hotel Portal Market case in Germany. Administrative Proceedings Decision Pursuant To Sec. 32 (1) Of The Act Against Restraints Of Competition (GWB).

Furthermore, Dyah Ochtorina Susanti, argued that in the main study the case approach was the ratio decidendi or reasoning, namely the assembly's consideration in compiling a decision until the decidendi ratio or reasoning became a reference in preparing arguments in solving the problem being studied. ${ }^{6}$

The comparative approach used in this study, the central element in comparative law is the comparison of law in the legal system family qualifications which only compare norms, Indonesian and German rules, especially the elements of rules and principles contained in a country are the main instruments in law enforcement. A rule is formed as a law enforcement instrument including the organizational structure and institutions that carry out the duties and authorities.

Furthermore, Michael Bogdan, argued that comparison means confronting the comparable elements of two or more legal systems against each other to find similarities between those systems. ${ }^{7}$ The comparative approach in this dissertation includes the comparison of decisions on business competition cases by the Bundeskartellamt in Germany.

The source of the primary legal materials used in this writing is Law No.5/1999, Commission Regulation No. 1 of 2019 concerning Procedures for Handling Cases of Monopolistic Practices and Unfair Business Competition. Secondary legal materials, including all publications on business competition law and civil procedural law.

\section{Results and Discussion}

Indonesia as a legal state that is oriented to the European continental legal system and order (civil law system), with the ideology of Pancasila and the 1945 Constitution of the Republic of Indonesia, of course, has characteristics in its legal system and institutions.

Regarding the legal system, furthermore, J.J.H. Bruggink in Arief Sidharta's book reveals that the legal system consists of three elements that have certain interrelated independence, namely: ${ }^{8}$

a. The ideal element, is formed by a system of meaning from the law which consists of rules and principles. It is this element obtained by the jurists that is called the legal system;

b. The operational element consists of all organizations and institutions established in a legal system; and

c. The actual element is the whole decision and concrete actions related to the system of meaning of the law, both from the office bearer and from members of the community in which there is a legal system.

In the process of law enforcement, it is necessary to have organizational and institutional elements that carry out the duties of these rules, in other words carry out statutory orders. In the constitutional system, the state divides three forms of institutions, namely the executive, legislative and judiciary. Apart from these three state institutions, the state also forms nonstructural state institutions. Furthermore, Isharyanto stated that non-structural state institutions as "special agencies" are a symptom that can be said to be new in the dynamics of exercising modern state power. ${ }^{9}$

\footnotetext{
${ }^{5}$ Ibid, h.95

${ }^{6}$ Dyah Octhtorina Susanti dan A'an Efendi, Penelitian Hukum (Legal Research),(Jakarta:Sinar Grafika, 2015),h.110

7 Michael Bogdan, Pengantar Perbandingan Sistem Hukum,(Bandung:Nusamedia, 2010),h.8

${ }^{8}$ J.J.H. Bruggink terjemahan Arief Sidharta, Refleksi Tentang hukum,(Bandung: Citra Aditya Bakti,1999). h.140

${ }^{9}$ Isharyanto,Hukum Kelembagaan Negara (Studi Hukum dan Konstitusi mengenai Perkembangan Ketatanegaraan Republik Indonesia),(Surakarta:Fakultas Hukum Universitas Sebelas Maret,2015),h.210. 
State institutions are sometimes referred to as government institutions, non-departmental government institutions, or just state institutions. Some are formed based on or because they are given power by the Constitution, some are formed and get their powers from the law, and some are even formed based on a Presidential Decree. Of course, the hierarchy or ranking of positions depends on the degree of regulation according to the prevailing laws and regulations. ${ }^{10}$

The Business Competition Supervisory Commission (KPPU) is a non-structural state institution based on Article 1 of Presidential Decree No.75 of 1999 concerning the Business Competition Supervisory Commission states that Paragraph (1) "With this Presidential Decree a Business Competition Supervisory Commission is established hereinafter referred to as the Commission". Paragraph (2) "The commission as referred to in paragraph (1) is a non-structural institution that is independent from the influence and power of the government and other parties".

In carrying out its duties and authorities, KPPU has a quasi-judicial nature and form. Furthermore, the notion of quasi judicial $^{11}$ 1) proceeding conducted by an administrative or executive official that is similar to a court proceeding, e.g. a hearing. A court may review a decision arising from a quasi-judicial proceeding; 2) A judicial act performed by an official who is either not a judge or not acting in his or her capacity as a judge.

The Business Competition Supervisory Commission (KPPU) is a special tool that has the task of not only creating order in business competition, but also playing a role in creating and maintaining a conducive business competition climate. Even though the Business Competition Supervisory Commission (KPPU) has a law enforcement function, it is not a special court for business competition, so it is not authorized to impose both criminal and civil sanctions. KPPU is more directed towards administrative institutions and the inherent authority is administrative authority, so that the sanctions imposed are administrative sanctions. ${ }^{12}$

Johnny Ibrahim further stated that as the case with commissions in several countries, KPPU is an independent institution and is detached from the influence and power of the government and any parties (Article 30 paragraph 2). On this basis, the commission is directly responsible to the president as the chief executive (Article 30 paragraph 3 ). It is different from the same commission in South Korea which is responsible to the Minister of Economic Planning Board. In Japan the FTC (Fair Trade Commission) is responsible directly to the Prime Minister, in Germany the Bundeskartellamt is responsible to the Federal Minister of Economy, in Australia the ACCC (Australian Competition and Consumer Commission) is responsible to the Minister of Finance and the Minister of Industry and Technology. ${ }^{13}$

The comparation of law on the settlement of business competition cases in Germany by Bundeskartellamt or BKarTA As the implementer of the Anti-Restrictions on German Business Competition Law (Cartel Law) which was promulgated in 1958, an independent institution was formed under the Federal Ministry of Economy, which is called Bundeskartelamt, namely the German Antimonopoly Agency (BKartA). ${ }^{14}$

The proceedings at BKartA are as follows. Within the BKartA organizational structure the one that has the authority to decide a case is the Decision Making Section, which consists of a chairman and two members. Based on Article 51 paragraph (2) a case decided by the Decision Making Section cannot be influenced by anyone, be it the President of BKartA or other parties. And the ruling of the decision making section is the ruling of BKartA. There are two ways to submit a case to BKartA, first, on

\footnotetext{
${ }^{10}$ Jimly Asshiddiqie,Perkembangan dan Konsolidasi Lembaga Negara Pasca Reformasi,( Jakarta:Sinar Grafika,2012), h.37

${ }^{11} \mathrm{https}$ ://www.law.cornell.edu/wex/quasi-judicial

12 Andi Fahmi Lubis,dkk, Hukum Persaingan Usaha Buku Teks Edisi Kedua, (Jakarta:Komisi Pengawas Persaingan Usaha (KPPU),2017).Op.Cit.h.313

13 Johnny Ibrahim, Hukum persaingan usaha filosofi, teori dan implikasi penerapannya di Indonesia, (Malang: Bayumedia Publishing, 2007).h.260.

${ }^{14}$ Andi Fahmi Lubis,dkk,Op.Cit. h.388
} 
the initiative of BKartA, and second, on reports or those submitted by certain parties. BKartA can open a process at the request/report of certain parties to be BKartA's initiative to protect the reporter. ${ }^{15}$

Bundeskartellamt (BKarTA) before making a decision on a case, BKartA provides an opportunity to go through the oral hearing stage, as follows: ${ }^{16}$

a. To the parties to convey their opinion or stance and to those invited at the request of one of the parties in the oral hearing.

b. To representatives from the economic sphere concerned to convey their stance on the process on specific cases.

c. In the case of Article 19 (dominant position) BKartA decides the trial based on oral trial; with the agreement of the parties it can be decided without an oral hearing. At the request of one of the parties or at the initiative of BKartA, the entire trial or part of it can be declared closed to the public, if the trial results in disturbing public order, particularly state security, or endangering the secrets of companies. After BKartA has obtained sufficient evidence and information on a particular case, BKartA will decide on the case.

BKartA decisions are accompanied by the reasons thereof, and accompanied by a notification regarding the legal means regulated by law which is conveyed to the parties based on the administrative law. For decisions regarding companies domiciled outside the area where this law applies, BKartA submits the decision to the person who has been assigned to BKartA as its proxy. If the company does not declare its power, BKartA submits the decisions through a federal state announcement. If a process/trial is not determined by BKartA through a decision, which is submitted to the parties concerned, the end of the parties shall be conveyed in writing. ${ }^{17}$

BKartA may establish a temporary order pending a final ruling on: ${ }^{18}$

1. Exemption based on Article 5 to 8, 17 paragraph (3) or Article 18, extension based on Article 10 paragraph (4), cancellation or amendment based on Article 12 paragraph (2).

2. Permission based on Article 42 paragraph (1), cancellation or amendment based on Article 42 paragraph (2) second sentence.

3. A decision based on Article 12 paragraph (1), Article 15 paragraph (3), Article 16, Article 22, Article 23 paragraph (3), Article 26 paragraph (4), Article 29 paragraph (3), Article 32, Article 36 paragraph (1), Article 40 paragraph (3) or Article 42 paragraph (2).

The Bundeskartellamt verdict on the Hotel Portal Market case in Germany. Administrative Proceedings Decision Pursuant To Sec. 32 (1) Of The Act Against Restraints Of Competition (GWB). Regarding the examination of violations of Article 1 of the German Law against the Curb of Competition (German Competition Law, GWB) / Article 101 (1) of the Treaty on the Functions of the European Union (TFEU), the 9th Decision Division decided as follows on 22 December 2015 according to with section 32 (1) GWB, as follows: ${ }^{19}$

1. It is hereby found that the tariff clause and parity conditions were agreed between Respondent 1 and 2 and their contract partners in sections 2.2.1 and 7.2 (a) of the General Terms and Conditions in that version dated 1 July 2015, in the form of "Preferred Membership," And in other individual agreements whose content corresponds to it, violates anti-monopoly laws as far as hotels and other accommodation located in Germany are concerned.

2. Respondents 1 and 2 are hereby prohibited from continuing to implement the stated clause as far as hotels and other accommodation located in Germany are concerned.

3. Respondents 1 and 2 were instructed to remove the best price clause (MFN clause) from the agreement or the General Terms and Conditions underlying the agreement, depending on the case being, to the extent that it concerns hotels and other accommodation located in Germany by 31 January 2016.

4. In the case of an individual contract, the order specified in section 3 above will also be fulfilled by a timely change to the contract at the next possible date, even if this does not become effective until after the deadline has expired..

5. Legal proceedings are terminated in all other aspects.

${ }^{15} \mathrm{Ibid}$.

${ }^{16}$ Ibid.h.389

${ }^{17} \mathrm{Ibid}$.

${ }^{18}$ Ibid.h.390.

${ }^{19}$ https://www.bundeskartellamt.de/SharedDocs/Entscheidung/EN/Entscheidungen/Kartellverbot/B9-121-

13.pdf?_blob=publicationFile\&v=2,diakses pada tanggal 19 April 2021.

www.scirj.org 
In the Law on Business Competition in Indonesia, the KPPU's authority is to examine and decide business competition cases, which include a preliminary examination stage and a follow-up examination stage which ends with a decision on business competition cases by business actors proven and not proven to have violated Law No.5/1999. Regarding the KPPU's decision as regulated in Article 43 of Law No.5/1999 Paragraph (3) and Paragraph (4), it states that:

(3) The Commission is obliged to decide whether or not there has been a violation of this law no later than 30 (thirty) days from the completion of the follow-up examination as referred to in paragraph (1) or paragraph (2).

(4) The Commission's decision as referred to in paragraph (3) must be read out in a session which is declared open to the public and immediately notified to the business actors.

The meaning of the decision according to the opinion of Sudikno Mertokusumo ${ }^{20}$ is that a judge's decision is a statement made by a judge as a state official who is authorized to do so, pronounced in court and aims to end or settle a case or problem between parties, but to settle cases other than the judge's decision there are still those who is called a judge's ruling.

Types of decisions in civil cases consist of final decisions and not final decisions, based on Article 185 Paragraph 1 HIR / Article 196 Paragraph 1 Rbg states that (1) “A judge's decision which is not the final decision, even if it must be pronounced in court, is not made separately, but only recorded in the trial minutes ". According to Sudikno Mertokusumo, a final decision is a decision that ends a dispute or case at a certain level of justice. Some of these final decisions are condemnatory, some are constitutive and some are declaratory. ${ }^{21}$

Condemnatoir verdict is a decision which punishes the defeated party to fulfill an achievement. The condemnatoir verdict regulates the rights of the plaintiff for the achievements he is demanding. Such punishment only occurs in connection with an agreement that is based on an agreement or a law, the performance of which can consist of giving, doing and not doing. In general, the condemnatoir verdict contains a penalty to pay a certain amount of money. Because with the condemnatory decision the defendant is obliged to fulfill the achievements, the rights of the plaintiffs that have been determined can be enforced by force (execution force). Thus, the condemnatoir decision has binding force, it also provides the basis for executorial rights to the plaintiff, which means giving the plaintiff the right to enforce the decision by force through the court. ${ }^{22}$

A constitutive decision is a decision that negates or creates a legal condition, such as termination of marriage, appointment of a guardian, granting interdiction, declaration of bankruptcy, termination of an agreement (Article 1266, Article $1267 \mathrm{BW}$ ) and so on. Generally, this constitutive decision cannot be implemented in the meaning of the word as mentioned above, because it does not stipulate the right to a certain achievement, the legal consequences or implementation do not depend on assistance from the defeated opponent. ${ }^{23}$

Declaratoir decisions are decisions whose contents are to explain or state what is legal, for example, that the child who is in dispute is a child born from a legal marriage. Also, every decision rejecting a lawsuit is a declaratory decision. In essence, all decisions, whether condemnatory or constitutive, are declaratory. ${ }^{24}$

Types of non-final decisions include interlocutory / intermediate decisions aimed at facilitating and expediting the case examination. Interlocutory decisions based on Article 185 Paragraph 1 HIR / Article 196 Paragraph 1 Rbg, although they must be pronounced in court, are not made separately, but only recorded in the trial minutes. Furthermore, Article 190 Paragraph 1 HIR / Article 201 Paragraph 1 Rbg determines that ${ }^{25}$ an interlocutory decision can only be appealed together with an appeal request against the final decision. Apart from Article 185 Paragraph 1 of the HIR which distinguishes between a final decision and a

\footnotetext{
${ }^{20}$ Sudikno Mertokusumo, Hukum Acara Perdata indonesia edisi ke tujuh,(Yogyakarta:Liberty,2006),h.143

${ }^{21}$ Ibid.h.229

${ }^{22}$ Ibid

${ }^{23}$ Ibid.h. 230

${ }^{24}$ Ibid.h. 230

${ }^{25}$ Ibid.
} 
decision that is not a final decision, Article $48 \mathrm{Rv}$ (Reglement op de Rechterlijke Rechtsvordering) distinguishes between preeparatoir decisions and interlocutoir decisions. ${ }^{26}$

Neng Yani further stated that first; a preparatory decision is a decision to prepare a case, for example combining two cases into one. Second, an interlocutoir decision is a judge's decision before giving a final decision, ordering one of the parties to prove something, or a decision that orders a local examination. ${ }^{27}$

Basically, in addition to Article $48 \mathrm{Rv}$, Article $332 \mathrm{Rv}$ (Reglement op de Rechterlijke Rechtsvordering) introduces two decisions of which types are not final decisions but in other forms, namely incidental and provisional decisions. Incidental decisions $^{28}$ are decisions that relate to incidents, that is, events that stop ordinary judicial procedures. Meanwhile, provisional decisions are decisions that respond to provisional demands, namely requests from the parties concerned to temporarily take preliminary actions for the benefit of one of the parties, before the final decision is passed. To implement the interlocutory decision in favor of this provisional claim, the Supreme Court has instructed that there is a special approval from the Supreme Court.

In line with the nature and types of court decisions, Taufik Makaro further stated that ${ }^{29}$ court decisions are something that the litigant parties really want or look forward to to resolve their disputes as well as possible. Because with the court ruling, the disputing parties expect legal certainty and justice in the cases they face.

A decision, usually issued by a judicial body. In its development, the state seems to provide a new understanding that law enforcement is not only carried out by judiciary bodies, but non-structural independent institutions that are only formed by law and outside the institutional structure in the constitutional and state administration system. Uniquely, the KPPU's decisions are analogous to court decisions and are considered to be the same. Until now, there is no clarity in thinking in Law No.5 / 1999 that KPPU's decisions have permanent legal force, so it is necessary to investigate definitions and theories regarding decisions that have permanent legal force at least to find this meaning..

Interpreting the word is what the speaker wants (does). However, interpreting the word is also what is meant by the sentence. The meaning of utterance - in the meaning of proportional content, is the "objective" side of this meaning. The meaning of the speaker - in the three forms of self-reference meaning of the sentence, the illocutionary dimension of the act of speaking, and the meaning of understanding by the listener - is the subjective side of meaning. ${ }^{30}$

This subjective-objective dialectic does not stop the meaning of meaning and for that it does not abolish the objective structure. The objective side of the discourse itself can be taken in two ways; it can interpret what the discourse is and what the discourse is about. What is the discourse is the "meaning" and what the discourse about is the "reference". The difference between meaning and reference has been introduced in modern philosophy by Gottlob Forge in his well-known paper "Ueber Sinn und Bedeutung" which has been translated into English. "On Sense and Reference". ${ }^{31}$

Paul Ricoeur's opinion interprets the word from the objective side in the delivery and discourse of a sentence. In the judicial system, decisions are born from legal discovery procedures carried out by judges. As Sudikno Mertokusumo's opinion ${ }^{32}$, that in order to be able to resolve or end a case or dispute as precisely as possible, a judge must first know objectively about the actual case as the basis for his decision and not a priori find that the decision is being considered and then construed. The judge will know the actual event from the evidence. Thus it is not that the decision is born in a priori process and then the evidence is

\footnotetext{
${ }^{26}$ Ibid.h. 231

${ }^{27}$ Neng Yani Nurhayani, Hukum acara Perdata,(Bandung:Pustaka Setia, 2015), h.182.

${ }^{28}$ Sudikno Mertokusumo, Op.Cit.h.231.

${ }^{29}$ Taufik Makaro,Op.Cit.h.124

${ }^{30}$ Paul Ricoeur, Teori Interpretasi (Membelah Makna dalam Anatomi Teks),(Jogjakarta:IRCiSoD, 2014),h.46-47

${ }^{31}$ Ibid.h.47

${ }^{32}$ Sudikno Mertokusumo,Op.Cit. ,h.199
} 
constructed or the consideration of the evidence is designed, but it must first be considered whether it is proven or not and then arrive at the decision.

After the judge deems proven that the incident has become a dispute, which means that the judge has been able to contravene the disputed event, the judge must determine what legal regulations are to control the dispute between the two parties. he must find the law; it must qualify the events which it considers proven. ${ }^{33}$ Therefore, the quality of the decision depends on the flow of thought and the ability of the judge to find the truth in a case.

The discussion regarding decisions that have permanent legal force, in the Law of the Republic of Indonesia Number 14 of 1985 concerning the Supreme Court does not regulate the meaning of decisions having permanent legal force in civil cases. However, we can refer to the elucidation of Article 195 of the Revised Indonesian Reglemen ("HIR") as a provision of civil procedural law in Indonesia, which reads as follows: ${ }^{34}$ In a civil case because the winning party has obtained a judge's decision to convict his opponent, they have the right with the means permitted by law to force the opposing party to comply with the judge's decision. This right is appropriate, because if there is no possibility of coercing the convicted person then the judiciary will be useless.

In this condition, there is no other way for the winning party than to exercise its right by means of a judge to carry out the decision, but the decision must actually have been implemented, have obtained definite strength, meaning that all legal avenues are against the decision has been used, or is not used because it has expired, unless the verdict is declared to be enforceable immediately, despite opposition, appeal or cassation. ${ }^{35}$

In line with this opinion, the KPPU's decision has permanent legal force of Article 46 Paragraph (1) of Law No.5 / 1999 that "If there are no objections, the Commission's decision as referred to in Article 43 paragraph (3) has permanent legal force" . Again, it is emphasized that in Article 46, nothing is explained in Law No.5 / 1999, which means that the KPPU's decision has permanent legal force.

Furthermore, Mustafa Kamal Rokan stated that if the Commission's Decision states that an act is proven to have violated the provisions of Law No.5 / 1999, then the next process will continue to the execution stage of the Commission's decision. Based on Article 47 of Law No.5 / 1999, the commission has the authority to impose administrative sanctions in the form of cancellation of agreements, orders to cease activities, cease abuse of dominant position, cancellation of mergers, consolidations, acquisitions, as well as stipulation of compensation payments and fines. The execution stage aims to ensure that the parties subject to sanctions fulfill their obligations. ${ }^{36}$

Types and characteristics of KPPU's decisions on business competition cases, namely First, the types of KPPU's decisions are condemnatory decisions which have the meaning of punishing business actors who are proven to have violated Law No.5 / 1999, namely monopolistic practices and unfair business competition. The characteristics of the Condemnatoir Decision can be seen in the Decision on Case Number 27 / KPPU-M / 2020 concerning Alleged Delay in Notification of Takeover of Dei Holdings Limited Shares by Travel Circle International (Mauritius) Limited and initially suspected of violating Article 29 of Law No.5 / 1999 Jo. Article 5 PP Number 57 Year 2010. KPPU subsequently gives the following decisions:

1. Declare that the Reported Party is legally and convincingly proven to have violated Article 29 of Law Number 5 Year 1999 in conjunction with Article 5 of Government Regulation Number 57 Year 2010.

2. To punish the Reported Party to pay a fine of Rp1,000,000,000.00 (one billion rupiah) which must be deposited in the State Treasury as a payment for income from fines for violations in the field of business competition through a Government Bank with an acceptance code 425812 (Income Penalty Violation in the Field of Business Competition).

\footnotetext{
${ }^{33}$ Ibid.h.200
}

34 http://www.hukumonline.com/klinik/detail/lt50b2e5da8aa7c/kapan-putusan-pengadilan-dinyatakan-berkekuatan-hukumtetap,diakses pada tanggal 2 April 2021.

35 Ibid.

${ }^{36}$ Mustafa Kamal Rokan,Hukum Persaingan Usaha (Teori dan Praktiknya di Indonesia),(Jakarta:Raja Grafindo,2012),h.284. 
3. Order the Reported Party to pay a fine no later than 30 (thirty) days after this Decision has permanent legal force (inkracht).

4. Instruct the Reported Party to report and submit a copy of proof of payment of said fine to KPPU.

5. Instruct the Reported Party to submit a bank guarantee of $20 \%$ (twenty percent) of the fine amount to KPPU no later than 14 (fourteen) working days after receiving the notification of this Decision.

Second, the nature of the KPPU's decision is non-executable in the sense that it must use the court viat as referred to in Article 46 Paragraph (2) of Law No.5 / 1999 that "the Commission Decision as referred to in paragraph (1) requires a decision of execution to the District Court". Theoretically the verdict has executable title. The executorial power is a power to carry out decisions. Because the decision ${ }^{37}$ expressly stipulates the rights or the law to be realized later, the judge's decision has executorial power, namely the power to enforce what is determined in that decision by force by state officials.

\section{Conclusion}

\section{Conclusion}

Berdasarkan uraian pada sub bab pembahasan, dapat disimpulkan bahwa:

1. Decision of the Business Competition Supervisory Commission (KPPU) is the result of the Commission Council's assessment read out in an open session to the public covering the occurrence of violations and imposition of sanctions or the absence of violations by business actors.

2. The meaning of the KPPU's decision is a decision that has permanent legal force, which is in a non-executable condemnatoir type.

\section{Suggestion}

Based on the above conclusions, the researcher provides the following suggestions:

1. In order for Article 46 Paragraph (2) of Law No.5 / 1999 to be unambiguous, it is necessary to provide an explanation through a government regulation regarding the meaning of permanent legal force in the KPPU's decision.

2. Lawmakers and the government need to amend the KPPU's position and authority, which was originally a state auxiliary body and quasi judicial into sub-ordination of judicial institutions so that KPPU decisions have an executorial title.

\section{Bibliography}

\section{Books}

Andi Fahmi Lubis,dkk, Hukum Persaingan Usaha Buku Teks Edisi Kedua, (Jakarta:Komisi Pengawas Persaingan Usaha (KPPU),2017).

L. Budi Kagramanto, Larangan Persekongkolan Tender (Perspektif Hukum Persaingan Usaha), (Surabaya:Srikandi, 2008).

Mustafa Kamal Rokan,Hukum Persaingan Usaha (Teori dan Praktiknya di Indonesia),(Jakarta:Raja Grafindo,2012).

Neng Yani Nurhayani, Hukum acara Perdata,(Bandung:Pustaka Setia, 2015).

I Made Pasek Diantha dalam I Made Sarjana, Prinsip Pembuktian dalam Hukum Acara Persaingan Usaha,(Disertasi:Universitas Airlangga, 2012).

Isharyanto,Hukum Kelembagaan Negara (Studi Hukum dan Konstitusi mengenai Perkembangan Ketatanegaraan Republik Indonesia),(Surakarta:Fakultas Hukum Universitas Sebelas Maret,2015).

J.J.H. Bruggink terjemahan Arief Sidharta, Refleksi Tentang hukum,(Bandung: Citra Aditya Bakti,1999).

Jimly Asshiddiqie,Perkembangan dan Konsolidasi Lembaga Negara Pasca Reformasi, ( Jakarta:Sinar Grafika,2012).

Johnny Ibrahim, Hukum persaingan usaha filosofi, teori dan implikasi penerapannya di Indonesia, (Malang: Bayumedia Publishing, 2007).

Michael Bogdan, Pengantar Perbandingan Sistem Hukum,(Bandung:Nusamedia, 2010).

Peter Mahmud Marzuki,Penelitian Hukum,(Jakarta:Prenada Media,2005).

Paul Ricoeur, Teori Interpretasi (Membelah Makna dalam Anatomi Teks),(Jogjakarta:IRCiSoD, 2014).

Sudikno Mertokusumo, Hukum Acara Perdata indonesia edisi ke tujuh,(Yogyakarta:Liberty,2006).

Taufik Makaro, Pokok-Pokok Hukum Acara Perdata,(Jakarta:Rineka Cipta, 2009).

Undang-Undang No. 5 Tahun 1999 tentang Larangan Praktik Monopoli dan Persaingan Usaha Tidak Sehat.

Putusan Perkara Nomor 27/KPPU-M/2020.

\section{Internet}

\footnotetext{
${ }^{37}$ Sudikno Mertokusumo, Op.Cit,h.220
} 
http://www.hukumonline.com/klinik/detail/lt54dc318596a4d/perbedaan-antara-hir-dan-rbg.

http://www.hukumonline.com/klinik/detail/lt50b2e5da8aa7c/kapan-putusan-pengadilan-dinyatakan-berkekuatan-hukum-tetap. https://www.law.cornell.edu/wex/quasi-judicial 